\title{
MOTIVASI MAHASISWA MEMANFAATKAN FASILITAS PERPUSTAKAAN FAKULTAS \\ STUDI KOMPARATIF ANTARA MAHASISWA DI FAKULTAS EKSAKTA DAN NON EKSAKTA
}

\author{
Oleh Wiyarsih
}

\section{INTISARI}

Tujuan perpustakaan perguruan tinggi adalah mendukung terlaksananya Tri Dharma Perguruan Tinggi yaitu memfasilitasi program pendidikan, penelitian, dan pengabdian pada masyarakat. Kualitas perpustakaan perguruan tinggi menjadi salah satu indikator mutu pendidikan di perguruan tinggi.

Kondisi perpustakaan di UGM pada umumnya belum dapat memberi layanan yang bermutu. Di samping itu terjadi fenomena adanya penurunan pemustaka yang memanfaatkan perpustakaan dari tahun ke tahun. Untuk itu penelitian ini bermaksud untuk mengetahui bagaimana motivasi mahasiswa memanfaatkan perpustakaan fakultas dan faktor-faktor apa yang mempengaruhinya. Oleh karena itu penelitian ini menggunakan studi komparatif antara mahasiswa fakultas eksakta dan non eksakta.

Penelitian ini menggunakan metode deskriptif dengan pendekatan kualitatif. Informan dalam penelitan ini adalah para mahasiswa anggota perpustakaan dan penanggung jawab Perpustakaan Fakultas Teknik UGM dan Fisipol UGM. Data yang terkumpul melalui studi kepustakaan, observasi, wawancara, dan studi dokumentasi dianalisis secara kualitatif. Analisis data dilaksanakan melalui reduksi data, display data, pengambilan kesimpulan, dan verifikasi.

Hasil penelitian menunjukkan bahwa dari tiga elemen motivasi yaitu kebutuhan, dorongan, dan tujuan, sebagian besar informan baik dari Fakultas Teknik UGM maupun Fisipol UGM dalam memanfaatkan perpustakaan fakultas mempunyai nAch. tinggi. Sebagian besar informan memanfaatkan perpustakaan karena kebutuhan meningkatkan prestasi. Sebagian besar informan memanfaatkan perpustakaan karena mendapat dorongan dari diri sendiri, dosen, dan teman. Sebagian besar informan berpendapat bahwa pemanfaatan perpustakaan berpengaruh terhadap IP, tetapi tinggi rendahnya IP tidak mempengaruhi sebagian besar informan dalam memanfaatkan perpustakaan.

Hasil penelitian ini juga menunjukkan bahwa semua faktor-faktor penting dari perpustakaan seperti koleksi, sarana prasarana dan layanan perpustakaan mempengaruhi motivasi mahasiswa memanfaatkan perpustakaan fakultas. Sebagian besar informan dari Fakultas Teknik UGM berpendapat bahwa jumlah buku sudah memadai dan sesuai dengan kebutuhan, sarana prasarana cukup memadai dan menilai positif terhadap layanan yang meliputi petugas, waktu layanan, tata tertib, dan situasi kondisi perpustakaan. Semua faktor tersebut telah memperkuat motivasi para informan memanfaatkan perpustakaan fakultas.

Sebagian besar informan dari Fisipol UGM berpendapat bahwa koleksi perpustakaan fakultas sudah berkualitas sehingga dapat memperkuat motivasi mahasiswa memanfaatkan perpustakaan. Dalam hal sarana prasarana, sebagian besar informan mengatakan bahwa sarana prasarana masih dirasa kurang sehingga belum memperkuat motivasi mahasiswa memanfaatkan perpustakaan. Dari faktor layanan, yang memperkuat motivasi sebagian besar informan adalah dari segi petugas, tata tertib, dan yang belum memperkuat motivasi mahasiswa adalah dari segi waktu layanan dan situasi kondisi perpustakaan.

Dari hasil penelitian ini juga menunjukkan bahwa faktor-faktor dari luar perpustakaan yaitu dosen, teman, diri sendiri dan orang tua mahasiswa, ternyata yang paling mempengaruhi para informan dari Fakultas Teknik UGM dalam memanfaatkan perpustakaan adalah faktor diri sendiri dan dosen, kemudian baru teman dan akhirnya orang tua mahasiswa. Di Fisipol UGM, yang paling mempengaruhi sebagian besar informan memanfaatkan perpustakaan adalah dosen, kemudian dari diri sendiri, dan teman, sedangkan faktor orang tua tidak begitu mempengaruhi. Dengan demikian faktor diri sendiri, dosen dan teman mempunyai pengaruh yang besar kepada mahasisiswa dalam memanfaatkan perpustakaan. Di antara ketiga faktor tersebut, dosen yang paling mempengaruhi para informan baik dari Fakultas Teknik UGM maupun Fisipol UGM, sehingga dosen berperan penting dalam mendorong para mahasiswa memanfaatkan perpustakaan.

Kata kunci: motivasi, mahasiswa, pemanfaatan, perpustakaan

*) Pustakawan UGM 


\section{LATAR BELAKANG MASALAH}

Keberadaan perpustakaan di suatu
lembaga atau organisasi adalah
mendukung luk
mencapai tujuannya, begitu pula dengan perpustakaan di perguruan tinggi. Menurut Sulistyo-Basuki (1993), perpustakaan perguruan tinggi ádalah perpustakaan yang terdapat pada perguruan tinggi, badan bawahannya, maupun lembaga yang berafiliasi dengan perguruan tinggi, dengan tujuan utama membantu perguruan tinggi mencapai tujuannya. Menurut Rachman Hermawan S. dan Zulfikar Zen (2006: 34), secara umum tujuan perpustakaan perguruan tinggi adalah untuk menunjang Tri Dharma Perguruan Tinggi, yaitu menyelengggaraan pendidikan, penelitian dan pengabdian pada masyarakat. Secara khusus adalah untuk membantu para dosen dan mahasiswa serta tenaga kependidikan di perguruan tinggi itu dalam proses pembelajaran. Mengingat pentingnya perpustakaan perguruan tinggi dalam penyelenggaraan pendidikan, maka perpustakaan perguruan tinggi telah menjadi salah satu indikator mutu pendidikan di perguruan tinggi. Makin baik perpustakaannya makin baik pula mutu luaran perguruan tinggi tersebut.

Agar perpustakaan perguruan tinggi dapat mendukung perguruan tinggi tersebut maka perpustakaan harus didukung dengan fasilitas yang memadai, sumber daya manusia, dan pelayanan yang berkualitas. Di samping itu perpustakaan juga harus dapat mengikuti perubahan perilaku pengguna seiring dengan perkembangan teknologi informasi dan komunikasi di era globalisasi ini. Menurut Mustafa (2003), untuk mendukung mutu pendidikan, perpustakaan harus mampu membangun layanan yang bermutu pula, yaitu layanan yang sesuai dengan kebutuhan pengguna yang meliputi materi, format, waktu, aturan, dan pelayanan yang sesuai. Layanan yang bermutu akan menarik pemustaka, khususnya mahasiswa, untuk rajin berkunjung ke perpustakaan dalam rangka mencari data, literatur dan informasi lainnya yang berkait dengan kegiatan akademiknya.
Universitas Gadjah Mada (UGM) sebag: universitas yang besar juga mempunyai jumla perpustakaan yang besar pula, yaitu sekitar 6 perpustakaan yang tersebar di fakultas, pus $\varepsilon$ studi dan lembaga, termasuk Perpustakaan UGN sebagai perpustakaan pusatnya. Dengan jumla perpustakaan yang besar tersebut apabil semuanya dikelola dengan baik da dimanfaatkan secara maksimal oleh pemustak maka merupakan kekayaan potensial yang aka mendukung UGM mencapai visi-misinya, yait mewujudkan UGM sebagai universitas riset kela dunia. Namun sampai saat ini kondisi secar umum perpustakaan di UGM belum dape memberi layanan yang bermutu, baik dari sę sarana prasarana, koleksi maupun layananny sendiri. Di sisi lain, terjadi fenomena bahw sebagian besar perpustakaan di UGM belur banyak dimanfaatkan oleh mahasiswa maupu dosen bahkan terjadi penurunan jumla pemustaka yang memanfaatkan perpustakaa dari tahun ke tahun. Apabila perpustakaan tida tanggap terhadap masalah ini maka perpustakaa di UGM akan terancam sepi dari pengunjung.

Untuk itu perlu diketahui mengapa terjac masalah di atas dan perlu ada upaya-upaya aga tingkat pemanfaatan perpustakaan dapat lebi meningkat. Penelitian ini dimaksudkan untu mengetahui bagaimana motivasi mahasisw memanfaatkan fasilitas perpustakaan fakulta dan faktor-faktor apa yang mempengaruk motivasi mahasiswa memanfaatkan fasilita perpustakaan. Dengan mengetahui hal tersebr maka perpustakaan dapat melakukan berbagi upaya sehingga para mahasiswa termotiva: untuk memanfaatkan fasilitas perpustakaa fakultasnya.

\section{METODE PENELITIAN}

Penelitian ini merupakan penelitia deskriptif dengan pendekatan kualitati Penelitian ini dilakukan di Perpustakaan Fakulta Teknik UGM sebagai fakultas eksakta dan c Perpustakaan Fisipol UGM sebagai fakultas nor eksakta. Penelitian dilaksanakan mulai 
September 2008 sampai 3 Oktober 2008. Teknik pengambilan sampel dalam penelitian ini adalah sampling pusposif. Sampel (informan) dalam penelitian ini adalah mahasiswa S1 dan S2 yang menjadi anggota perpustakaan dan penanggung jawab di Perpustakaan Fakultas Teknik UGM dan Fisipol UGM. Jumlah sampel (informan) pada penelitian ini untuk mahasiswa dari Fakultas Teknik UGM berjumlah 7 orang sedangkan dari Fisipol UGM 9 orang mahasiswa. Metode pengumpulan data dalam penelitian ini adalah studi kepustakaan, observasi, wawancara, dan dokumentasi. Alat pengumpulan data dalam penelitian ini adalah peneliti sendiri, catatan lapangan, tape recorder dan kaset dan panduan wawancara. Adapun langkah-langkah analisis data yang digunakan dalam penelitian ini adalah menurut Nasution (2003: 129) yakni (1) reduksi data, (2) "display" data, (3) mengambil kesimpulan dan verifikasi. Teknik pemeriksaan data dilakukan dengan triangulasi.

\section{HASIL DAN PEMBAHASAN}

\section{A. Pandangan Mahasiswa terhadap Perpus- takaan Fakultas}

Dari hasil penelitian dapat diketahui bahwa para informan dari Fakultas Teknik UGM mempunyai bermacam-macam pandangan terhadap Perpustakaan Fakultas Teknik UGM. Pandangan para informan yang baik terhadap perpustakaan yaitu: cukup bagus, bersih, sesuai harapan, ada perkembangan, memuaskan, fasilitas lengkap, kebijakan cukup bagus, pelayanan ramah, cukup srategis, koleksi cukup memadai, suasana tenang, stabil, nyaman dan kondusif dan meningkatkan pengetahuan. Sedangkan pandangan para informan yang kurang baik terhadap perpustakaan adalah pelayanan standar, belum sesuai harapan, sarana prasarana standar.

Pandangan para informan dari Fisipol UGM yang baik terhadap Perpustakaan Fisipol UGM adalah cukup bagus, dekat, sesuai harapan, cukup memadai, memenuhi kebutuhan, pelayanan cukup baik, ada perbaikan, petugas sudah membantu, kebijakan cukup bagus, peraturan tidak terlalu ketat dan suasana cukup baik. Sedangkan pandangan para informan dari Fisipol UGM yang belum baik terhadap Perpustakaan Fisipol UGM yaitu buku belum urut, pelayanan standar, kurang melibatkan pengguna, belum ideal, belum sesuai dengan harapan dan sarana prasaran belum lengkap.

Dari pandangan para informan di atas dapat diketahui bahwa pandangan mereka terhadap perpustakaan fakultas sangat bermacam-macam tergantung dari faktor internal dan eksternalnya. Tetapi dari berbagai macam pandangan tersebut ternyata sebagian besar informan baik dari Fakultas Teknik UGM maupun Fisipol UGM mempunyai pandangan bahwa perpustakaan fakultas sudah sesuai dengan harapan mereka. Pandangan para informan di atas akan memengaruhi perilakunya dan selanjutnya akan menentukan motivasi mereka dalam memanfaatkan perpustakaan fakultas.

Para informan yang masih mempunyai pandangan yang belum baik terhadap perpustakaan fakultas mempunyai harapanharapan terhadap perpustakaan fakultas. Dari hasil penelitian dapat diketahui bahwa sebagian besar informan di Fakultas Teknik UGM mempunyai harapan adanya buku yang lebih up to date penambahan fasilitas dan adanya kenyamanan. Di Fisipol UGM, sebagian besar informan mempunyai harapan adanya penambahan fasilitas, buku dan perbaikan penataan ruang.

\section{B. Motivasi Mahasiswa Memanfaatkan Perpus- takaan Fakultas}

\section{a. Kebutuhan Mahasiswa}

Sesuai dengan teori Tiga Kebutuhan dari McCleland dkk, mahasiswa mempunyai tiga jenis kebutuhan yaitu kebutuhan untuk berprestasi (nAch.), kebutuhan kekuasaan (nPo.) dan kebutuhan untuk berafiliasi (nAff.). Dalam kaitannya dengan studinya, mahasiswa mempunyai kebutuhan untuk meningkatkan prestasi belajar (nAch.). Salah satu indikator mahasiswa yang berhasil 
dalam studinya ditunjukkan dengan prestasi belajar atau indeks prestasi (IP) yang tinggi.

Berdasarkan teori $n A c h$., mahasiswa dapat digolongkan menjadi tiga jenis yaitu maksimalis, konformis dan minimalis. Mahasiswa yang maksimalis akan berusaha untuk mencapai prestasi setinggi mungkin dalam studinya. Prestasi yang tinggi salah satunya ditunjukkan dengan IP yang tinggi, sehingga mahasiswa yang maksimalis juga akan berusaha untuk mencapai IP yang tinggi. Salah satu usaha yang dapat ditempuh untuk mencapai prestasi yang tinggi tersebut adalah dengan cara memanfaatkan perpustakaan. Mahasiswa yang konformis tidak berusaha mencapai IP yang tinggi tetapi hanya sekedar dapat lulus dalam setiap ujian, begitu pula dengan mahasiswa yang minimalis sehingga IP-nya rendah, di bawah standar kelulusan. Mahasiswa yang tergolong konformis dan minimalis akan memanfaatkan perpustakaan dengan terpaksa, misalnya karena ada tugas dari dosen.

Untuk memuaskan kebutuhan berprestasi, mahasiswa mempunyai beraneka ragam kebutuhan, seperti buku, jurnal, informasi, akses internet, sarana belajar dan lain-lain. Berbagai jenis kebutuhan tersebut tidak mungkin dapat dipenuhi sendiri. Cara yang paling efektif untuk memenuhi berbagai kebutuhan adalah dengan memanfaatkan perpustakaan yang telah disediakan oleh fakultas. Mahasiswa sebagai sivitas akademika mempunyai hak dan kewajiban. Salah satu kewajiban mahasiswa adalah membayar biaya perkuliahan. Dengan kewajiban tersebut mahasiswa berhak mendapat fasilitas yang disediakan oleh universitas maupun fakultas, sesuai dengan keputusan Majelis Wali Amanat No. 121/SK/MWA/2002 Anggaran Rumah Tangga UGM pada Bab XIX pasal 107 tentang Kemahasiswaan dan Alumni yang menyebutkan bahwa hak mahasiswa antara lain adalah memanfaatkan fasilitas dalam rangka kelancaran proses pembelajaran dan memperoleh layanan informasi yang berkaitan dengan program studi. Salah sat fasilitas yang dapat dimanfaatkan oleh par: mahasiswa adalah perpustakaan yan disediakan oleh fakultas. Mahasiswa yang baik tentu akan melaksanakan kewajiban das menggunakan haknya dengan sebaik baiknya.

\section{b. Dorongan Mahasiswa Memanfaatkaı Perpustakaan}

Mahasiswa dalam memanfaatkas perpustakaan tentu ada yang mendorong Menurut Sondang P. Siagian, dorongar tersebut dapat bersumber dari dalam dir mahasiswa (intrinsik) dan dapat bersumbe dari luar dirinya (ekstrinsik). Mahasisw: yang maksimalis akan memanfaatka perpustakaan karena dorongan dari dalan dirinya sendiri selain dari luar dirinya, tetap untuk mahasiswa yang kompromis dal minimalis biasanya memanfaatkas perpustakaan hanya apabila ada dorongas dari luar dirinya. Dorongan dari luar dir mahasiswa (ekstrinsik) yang mendoron: mahasiswa memanfaatkan perpustakaal fakultas tersebut dapat bersumber dari adany; stimuli dari perpustakaan sendiri maupun dar orang-orang yang mempengaruhinya sepert dosen, teman, dan orang tua mahasiswa.

Dari hasil penelitian dapat diketahui bahw: di Fakultas Teknik, sebagian besar informar memanfaatkan perpustakaan karena dorongaı mencari informasi dan referensi dan hal in berarti dorongan tersebut berasal dari dalan dirinya (instrinsik), sedangkan informan yan lainnya ada yang terdorong dari suasani perpustakaan yang kondusif (ekstrisik). D Fakultas Fisipol UGM, sebagian besa informan memanfaatkan perpustakaan jug: karena dorongan yang bersumber dari dalan dirinya yaitu kebutuhan terhadap buku Untuk informan yang lainnya mendapa dorongan dari luar dirinya yaitu dar perpustakaan.

Selain dorongan dari perpustakaan, dorongar juga dapat berasal dari dalam diri mahasisw: dan orang-orang di sekelilingnya terutam: 
dosen, teman dan orang tua mahasiswa. Dari hasil penelitian dapat diketahui bahwa di Fakultas Teknik UGM, dorongan terbesar bersumber dari dosen dan dari dalam diri mahasiswa sendiri, kemudian teman dan paling sedikit adalah dari orang tua mahasiswa. Sedangkan di Fisipol UGM, dorongan terbesar bersumber dari dosen, kemudian dari teman, diri sendiri dan yang paling sedikit juga dari orang tua mahasiswa. Alasan dari para informan mengapa dosen mendorong mereka memanfaatkan perpustakaan yaitu dosen memberi tugas dan menyuruh mahasiswa mencari literatur di perpustakaan. Alasan para informan mengapa teman mendorong mereka memanfaatkan perpustakaan adalah karena apabila ada teman dapat berdiskusi dan lebih lama di perpustakaan atau apabila teman mengajak ke perpustakaan. Alasan para informan mengapa diri sendiri mendorong mereka memanfaatkan perpustakaan adalah karena kebutuhan dan sudah dewasa sehingga harus mandiri. Dengan demikian berarti bahwa sebagian besar informan dari Fakultas Teknik UGM maupun Fisipol UGM termasuk mahasiswa yang maksimalis atau mempunyai motivasi tinggi memanfaatkan perpustakaan fakultas.

\section{c. Tujuan Mahasiswa Memanfaatkan Perpus- takaan}

Mahasiswa yang memanfaatkan perpustakaan tentu mempunyai tujuan. Dari hasil penelitian dapat diketahui bahwa sebagian besar informan dari Fakultas Teknik UGM memanfaatkan mempunyai tujuan untuk meminjam buku dan akses internet. Di Fisipol UGM, sebagian besar informan memanfaatkan perpustakaan dengan tujuan memenuhi tugas kuliah. Jadi dari berbagai tujuan tersebut dapat diketahui bahwa semua informan memanfaatkan perpustakaan pada umumnya adalah untuk memenuhi kebutuhan perkuliahan dalam rangka meningkatkan prestasi belajar.

\section{d. Hubungan antara Pemanfaatan Perpusta- kaan dengan IP Mahasiswa}

Berikut ini pendapat mahasiswa tentang hubungan antara pemanfaatan perpustakaan dengan IP mahasiswa, apakah dengan memanfaatkan perpustakaan, IP mahasiswa menjadi tinggi? Dari hasil penelitian dapat diketahui bahwa sebagian besar informan berpendapat bahwa dengan memanfaatkan perpustakaan dapat mempengaruhi IP mahasiswa.

\section{e. Hubungan antaran IP dengan Peman- faatan Perpustakaan}

Dari hasil penelitian ternyata semua informan baik dari Fakultas Teknik UGM maupun Fisipol UGM berpendapat bahwa tinggi rendahnya IP tidak mempengaruhi dalam pemanfaatan perpustakaan. Mereka tetap memanfaatkan perpustakaan walaupun IP mereka sudah tinggi sekalipun. Dari alasan para informan dapat diketahui bahwa mereka memanfaatkan perpustakaan tidak hanya untuk mencari IP tinggi tetapi juga ada alasan-alasan lainnya seperti untuk mencari ilmu, mencari informasi baru, meningkatkan kemampuan dan sebagainya. Jadi, IP hanya salah satu indikator dari prestasi mahasiswa. Indikator prestasi mahasiswa lainnya seperti wawasan yang luas, penguasaan ilmu, kemampuan menganalisis suatu masalah dan sebagainya.

\section{Pemanfaatan Perpustakaan}

Dari faktor-faktor di atas dapat digunakan untuk mengetahui bagaimana pemanfaatan perpustakaan oleh mahasiswa. Untuk mengetahui pemanfaatan perpustakaan oleh para informan di Perpustakaan Fakultas Teknik UGM dan Fisipol UGM dapat dilihat berikut ini:

\section{Durasi Kunjungan}

Dari hasil penelitian ini dapt diketahui bahwa sebagian besar informan baik dari Fakultas Teknik UGM maupun Fisipol UGM memanfaatkan perpustakaan rata-rata berdurasi 2 jam. Menurut keterangan para 
informan yang berkunjung rata-rata berdurasi 2 jam, waktu tersebut biasanya digunakan untuk membaca buku dan mengakses internet. Satu orang informan yang di perpustakaan berdurasi 3 jam adalah mahasiswa yang sedang skripsi karena mahasiswa tersebut lebih banyak memerlukan informasi maupun literatur. Sedangkan menurut keterangan para informan dari Fisipol UGM, biasanya apabila durasinya lama mereka menggunakan waktunya untuk mengakses internet dan atau membaca buku, apabila sebentar maka hanya meminjam atau mengembalikan buku.

\section{Frekuensi Kunjungan}

Dari hasil penelitian ini dapat diketahui bahwa sebagian besar informan dari Fakultas Teknik UGM berkunjung ke perpustakaan fakultas adalah $2 \mathrm{kalj}$ seminggu. Selain itu juga ditunjukkan bahwa frekuensi para informan memanfaatkan perpustakaan dipengaruhi oleh kepentingan dan tujuan mereka memanfaatkan perpustakaan.

3. Koleksi dan Fasilitas Perpustakaan yang Sering dimanfaatkan oleh Para Informan

Dari hasil penelitian dapat diketahui bahwa fasilitas yang sering dimanfaatkan oleh para informan dari Fakultas Teknik UGM adalah buku kemudian internet. Dengan demikian dapat disimpulkan buku dan internet merupakan kebutuhan penting mahasiswa Fakultas Teknik UGM. Di Perpustakaan Fisipol UGM, sebagian besar para informan dari Fisipol UGM memanfaatkan komputer OPAC, komputer internet dan buku. Dengan demikian dapat disimpulkan bahwa OPAC, buku dan internet merupakan kebutuhan penting mahasiswa Fisipol UGM.

\section{Hambatan dalam Memanfaatkan Perpustakaan}

Dalam memanfaatkan perpustakaan mungkin ada hambatan baik yang bersumber dari perpustakaan maupun dari mahasiswanya sendiri. Dari hasil penelitian dapat diketahui bahwa sebagian besar mahasiswa Fakultas Teknik UGM tidak mempunyai hambatan baik dari dirinya sendiri maupun dari fiha perpustakaan. Dengan demikian, paj informan sudah mendapat kemudahan da kepuasan dalam memanfaatkan perpustakaa1 Tidak adanya hambatan tersebut mungki disebabkan karena jumlah penggunany relatif sedikit sehingga lebih leluas memanfaatkan perpustakaan. Dari has penelitian juga dapat diketahui bahu ternyata semua informan dari Fisipol UGN mendapat kendala baik yang bersumb; dalam diri mahasiswa maupun dari fiha perpustakaan. Banyaknya hambatan yan dialami oleh para informan dari Fisipol UGN di atas mungkin salah satunya disebabka adanya perpindahan lokasi perpustakaa yang lebih sempit sehingga menimbulka banyak kendala baik tempat maupu fasilitasnya. Selain itu pemustaka juga relat banyak.

\section{Manfaat Berkunjung ke Perpustakaa} Fakultas

Dari hasil penelitian dapat diketahui bahw dengan memanfaatkan perpustakaa mempunyai banyak manfaat bagi par informan baik dari Fakultas Teknik UGN maupum Fisipol UGM. Manfai Perpustakaan Fakultas Teknik UGM ba६ para informan dalam menunjan pembelajaran terutama untuk mencari buk dan menambah ilmu. Dari hasil penelitia juga dapat diketahui bahwa Perpustakaa Fisipol UGM memberi banyak manfaat baई para informan terutama untuk mengerjaka tugas dari dosennya, kemudian dalar mencari buku dan untuk memenul kebutuhan pengetahuan. Jadi dari manfa: yang diperoleh para informan $\mathrm{di}$ ata menunjukkan bahwa para informa mendapatkan kepuasan dalam memanfaatka perpustakaan.

\section{Tingkat Pemanfaatan Perpustakaan}

Dilihat dari jumlah mahasiswa yan berkunjung ke Perpustakaan Fakultas Tekni UGM ternyata masih rendah. Sebagai conto pada bulan September 2008 jumla 
pengunjung ada 712 orang. Apabila jumlah tersebut dibagi 26 hari kerja maka rata-rata pengunjung per hari sekitar 28 pengunjung. Jumlah tersebut adalah sangat rendah apabila dibandingkan dengan seluruh jumlah mahasiswa Fakultas Teknik yang lebih dari 10.000 mahasiswa. Setelah penulis mengunjungi 8 perpustakaan jurusan ternyata jumlah pengunjung di perpustakaan jurusan jauh lebih tinggi. Hampir semua perpustakaan jurusan yang penulis kunjungi penuh mahasiswa yang sedang memanfaatkan perpustakaan. Dengan tingkat kunjungan yang rendah berarti pemanfaatan di Perpustakaan Fakutas Teknik UGM juga masih rendah. Rendahnya pemanfaatan di Perpustakaan Fakultas Teknik UGM salah satunya adalah karena adanya perpustakaan referensi di jurusan dimana dari segi lokasi lebih dekat dan dari segi koleksi lebih sesuai dengan referensi dari dosen.

Di Perpustakaan Fisipol UGM dilihat dari jumlah mahasiswa yang berkunjung ke Perpustakaan Fisipol jauh lebih tinggi dari pada di Perpustakaan Fakultas Teknik UGM. Sebagai contoh pada bulan September 2008 jumlah pengunjungnya adalah 2.395 orang. Apabila jumlah tersebut dibagi 26 hari kerja maka rata-rata pengunjungnya sekitar 90 orang. Dengan tingkat kunjungan yang tinggi berarti tingkat pemanfaatan di Perpustakaan Fisipol UGM juga tinggi. Banyaknya mahasiswa yang memanfaatkan perpustakaan fakultas salah satunya karena sebagian besar perpustakaan di jurusan belum dikelola secara profesional sehingga sebagian besar mahasiswa memanfaatkan perpustakaan fakultas.

\section{). Faktor-faktor dari Perpustakaan yang Mempengaruhi Motivasi Mahasiswa Memanfaatkan Perpustakaan Fakultas}

\section{Ketersediaan Koleksi Perpustakaan}

Dari hasil penelitian dapat diketahui bahwa semua informan dari Fakultas Teknik UGM berpendapat bahwa koleksi di Perpustakaan Fakultas Teknik UGM sudah sesuai dengan kebutuhan dan jumlahnya memadai. Walaupun demikian ada $71,43 \%$ dari mereka berpendapat bahwa bukunya kurang pembaharuan. Dengan demikian maka dapat disimpulkan bahwa faktor yang mempengaruhi motivasi mahasiswa memanfaatkan Perpustakaan Fakultas Teknik UGM adalah adanya koleksi yang sesuai dengan kebutuhan dan jumlahnya memadai .

Dari hasil penelitian dapat diketahui bahwa $77,78 \%$ informan dari Fisipol UGM berpendapat bahwa untuk koleksi buku di perpustakaan fakultas sudah berkualitas, tetapi ada 77,78 \% informan berpendapat bahwa jumlah buku masih kurang dan 66,67 $\%$ informan berpendapat bahwa buku kurang pembaharuan. Di samping itu sebagian juga berpendapat bahwa koleksi buku sudah lengkap tetapi ada yang berpendapat bahwa jumlah jurnal kurang dan belum up to date Sebagian informan juga mengeluhkan tentang penataan buku di rak yang belum tepat. Dengan demikian, dapat diketahui bahwa yang menjadi faktor motivasi mahasiswa Fisipol UGM memanfaatkan perpustakaan salah satunya karena koleksinya berkualitas sesuai dengan materi kuliah.

\section{b. Ketersediaan Sarana Prasarana Perpus- takaan}

Dari hasil penelitian dapat diketahui bahwa sebagian besar informan dari Fakultas Teknik UGM menilai sarana prasarana di Perpustakaan Fakultas Teknik UGM sudah memadai. Dengan demikian menurut penulis, sarana prasarana di Perpustakaan Fakultas Teknik UGM menjadi faktor yang dapat memotivasi sebagian besar informan untuk memanfaatkan perpustakaan fakultas. Di Perpustakaan Fisipol UGM, sebagian besar informan mengeluhkan terhadap sarana prasarananya sehingga menurut penulis, sarana prasarana di Perpustakaan Fisipol UGM belum memotivasi para informan memanfaatkan perpustakaan fakultas.

\section{c. Layanan Perpustakaan}


Dari hasil penelitian dapat diketahui bahwa sebagian besar informan dari Fakultas Teknik UGM menilai positif terhadap petugas dalam memberikan layanan kepada pengguna. Dengan demikian, petugas di Perpustakaan Fakultas Teknik UGM dapat memotivasi para informan memanfaatkan perpustakaan fakultas. Di Perpustakaan Fisipol UGM sebagian besar informan menilai petugasnya mampu dan paham terhadap tugas, tetapi masih ada informan yang menilai bahwa petugas tidak ramah dan masih pasif dalam memberikan layanan kepada pemustaka. Dengan demikian petugas yang mampu dan paham terhadap tugas tersebut dapat menjadi faktor yang memotivasi para informan memanfaatkan perpustakaan fakultas. Penilaian positif terhadap petugas di Perpustakaan Fakultas Teknik UGM tersebut salah satunya karena pengunjungnya relatif sedikit dibandingkan dengan pengunjung Perpustakaan Fisipol UGM sehingga secara psikologis dapat lebih siap dan leluasa dalam memberikan layanan. Sedangkan petugas di Perpustakaan Fisipol UGM pada waktu melayani banyak pengunjung, secara psikologis dapat mempengaruhi emosinya. Pelayanan yang kurang menyenangkan tersebut dapat membuat pemustaka enggan memanfaatkan perpustakaan lagi walaupun petugas tersebut mempunyai kemampuan dalam memberikan layanan.

\section{Waktu Layanan Perpustakaan}

Dari hasil penelitian dapat diketahui bahwa sebagian besar informan dari Fakultas Teknik UGM berpendapat bahwa waktu layanan di Perpustakaan Fakultas Teknik UGM sudah cukup memadai. Hal ini dapat memperkuat motivasi mereka memanfaatkan perpustakaan fakultasnya. Sebab mahasiswa yang memanfaatkan perpustakaan relatif sedikit sehingga lebih leluasa berada di perpustakaan dan apabila waktu layanannya diperpanjang sampai sore atau malam maka akan st bahkan tidak ada pengunjungnya.

Dari hasil penelitian ini dapat diketar bahwa di perpustakaan Fisipol UG] sebagian besar informan merasa kura waktu layanannya sehingga juga kura memotivasi para informan mema faatkan perpustakaan fakultasnya. Hal dipengaruhi oleh banyaknya pemusta yang memanfaatkan fasili perpustakaan sehingga waktu layanann dirasa kurang leluasa. Di samping i pelayanan di Perpustakaan Fisipol UG juga belum tepat waktu seperti ya tercantum dalam tahapan terakhir unt mencapai visinya yaitu pelayanan pri kepada pemustaka. Pelayanan yang tid tepat waktu akan merugikan d mengecewakan pemustaka.

\section{Tata Tertib Perpustakaan}

Dari hasil penelitian dapat diketal bahwa sebagian besar informan $d$ Fakultas Teknik UGM menilai tata terı di Perpustakaan Fakultas Teknik UG sudah baik tetapi $28,57 \%$ dari 7 inform mengeluhkan tentang waktu pinjamn yang masih kurang. Dengan demikic tata tertib di Perpustakaan Fakul Teknik UGM dapat menjadi faktor ya memperkuat motivasi mahasis' memanfaatkan perpustakaan fakultas.

Di Perpustakaan Fisipol UGM dalam 1 tata tertib, sebagian besar inform berpendapat bahwa tata tertibnya sud cukup bagus dan fleksibel tetapi mas ada informan yang merasa keberat terhadap denda yang diterapkan d kurang tepatnya waktu layanan. Deng demikian, tata tertib di Perpustaka Fisipol UGM dapat menjadi faktor ya memperkuat motivasi mahasis' memanfaatkan perpusta-kaan fakult Ketidaktepatan waktu layanan da! merugikan pemustaka yang akan d sedang memanfaatkan perpustaka; Dalam hal denda memang itu kebijak 
dari masing-masing perpustakaan fakultas dan hal itu dikenakan agar para pengguna mentaati peraturan perpustakaan.

\section{Situasi dan Kondisi Lingkungan Perpustakaan}

Dari hasil penelitian dapat diketahui bahwa sebagian besar informan dari Fakultas Teknik UGM berpendapat bahwa kondisi dan situasi di Perpustakaan Fakultas Teknik UGM sudah nyaman. Dengan demikian kondisi yang nyaman tersebut dapat menjadi faktor yang memperkuat motivasi mahasiswa memanfaatkan perpustakaan fakultas. Situasi dan kondisi di Perpustakaan Fakultas Teknik UGM yang sudah nyaman tersebut salah satunya karena penggunanya relatif sedikit sehingga lebih nyaman berada di perpustakaan.

Di Fisipol UGM, sebagian besar informan masih mengeluhkan kondisi dan situasi perpustakaan fakultas, tetapi sebagian berpendapat bahwa lokasinya lebih dekat dari pada sebelum pindah. Dengan demikian, situasi dan kondisi di Perpustakaan Fisipol UGM belum dapat memperkuat motivasi mahasiswa memanfaatkan perpustakaan fakultas. Kondisi tersebut salah satunya karena pindahnya ke lokasi baru yang lebih sempit. Namun demikian dengan perpindahan tersebut juga banyak yang menilai positif karena lokasinya lebih dekat dari kampusnya. Di samping itu di Perpustakaan Fisipol UGM dalam hal keamanan tas belum terjamin. Hal ini karena walaupun ada loker tetapi banyak yang sudah rusak dan tidak dapat dikunci lagi sehingga tidak berfungsi untuk mengamankan barang-barang milik pengunjung.

\section{E. Hubungan antara Fasilitas Perpustakaan dan Motivasi Mahasiswa Memanfaatkan Perpustakaan Fakultas}

Fasilitas perpustakaan pada intinya meliputi koleksi, sarana prasarana dan layanan perpustakaan. Adanya koleksi yang lengkap, memadai, beraneka ragam, mutakhir dan relevan dengan kebutuhan pemustaka maka akan menjadi daya dorong bagi pengguna untuk memanfaatkan perpustakaan dan hal itu berlaku sebaliknya. Sarana prasarana yang lengkap, aman, nyaman dan menarik akan menjadi daya dorong bagi pemustaka untuk memanfaatkan perpustakaan dan hal itu berlaku sebaliknya. Layanan yang lengkap dan berorientasi kepada pengguna maka akan menjadi daya dorong bagi pengguna untuk memanfaatkan perpustakaan dan hal itu berlaku sebaliknya.

Dari hasil penelitian dapat diketahui bahwa sebagian besar informan dari Fakultas Teknik UGM menilai bahwa fasilitas perpustakaan sudah memadai sehingga hal ini bisa memotivasi mahasiswa memanfaatkan perpustakaan fakultas. Tetapi masih ada $28,57 \%$ informan yang menilai bahwa fasilitas perpustakaan kurang lengkap. Dari hasil penelitian juga dapat diketahui bahwa $44,44 \%$ informan dari Fisipol UGM menilai bahwa fasilitas perpustakaan kurang lengkap, sedangkan informan yang lain berpendapat bahwa fasilitas perpustakaan sudah memadai dan bagus. Dengan demikian dari pendapat para informan tentang fasilitas yang kurang lengkap tersebut belum memperkuat motivasi mahasiswa memanfaatkan perpustakaan. Faktor fasilitas yang dapat memperkuat motivasi mahasiswa memanfaatkan perpustakaan fakultas adalah dari pendapat para informan tentang fasilitas yang memadai dan bagus.

Jadi jelas bahwa dengan semakin sempitnya ruang perpustakaan karena perpindahan lokasi mengakibatkan fasilitas di Perpustakaan Fisipol UGM menjadi berkurang walaupun letaknya lebih dekat dari semula. Kebijakan perpustakaan yang akan pindah lagi ke lantai tiga yang lebih luas adalah keputusan yang tepat karena lebih memperhatikan kepentingan pemustaka. 
Dari hasil penelitian tentang koleksi dan fasilitas yang sering dimanfaatkan oleh para informan dapat menunjukkan bahwa berbagai fasilitas tersebut mendorong atau memotivasi mahasiswa memanfaatkan perpustakaan. Jadi koleksi dan fasilitas yang bisa mendorong motivasi mahasiswa adalah koleksi dan fasilitas yang sangat penting atau dibutuhkan oleh para mahasiswa sehingga fasilitas itu dimanfaatkan.

Dari hasil penelitian juga dapat diketahui bahwa semua informan dari Fakultas Teknik UGM sering memanfaatkan buku dan sebagian besar informan sering memanfaatkan fasilitas komputer untuk akses internet. Hal ini berarti bahwa buku dan fasilitas komputer untuk akses internet adalah dua hal yang memotivasi para informan memanfaatkan perpustakaan fakultas. Di Perpustakaan Fisipol UGM, sebagian besar informan sering memanfaatkan komputer OPAC kemudian buku dan internet. Dengan demikian komputer OPAC, buku, dan internet adalah tiga hal yang dapat memotivasi para informan memanfaatkan perpustakaan fakultas.

\section{F. Faktor Diri Sendiri, Dosen, Teman dan Orang Tua Mahasiswa}

Selain dari perpustakaan, faktor-faktor yang dapat memengaruhi mahasiswa memanfaatkan perpustakaan dapat bersumber dari diri sendiri, teman, dosen dan orang tua mahasiswa. Dari hasil penelitian dapat diketahui bahwa sebagian besar informan dari Fisipol UGM memanfaatkan perpustakaan karena faktor dari dosen, dari teman dan diri sendiri. Di Fakultas Teknik UGM, faktor yang besar pengaruhnya terhadap mahasiswa dalam memanfaatkan perpustakaan fakultas adalah dari dosen dan diri mahasiswa sendiri, kemudian teman. Dengan demikian penulis berpendapat bahwa dosen dapat memegang peranan besar dalam mendorong mahasiswanya untuk memanfaatkan perpustakaan. Apabila dosen dalam memberi tugas diarahkan un mencari literatur di perpustakaan $\mathrm{m}$ i mahasiswa akan terdorong juga un memanfaatkan perpustakaan. Hal tersel juga berarti bahwa dosen-dosen di Fakul Teknik UGM dan di Fisipol UGM suc mengarahkan mahasiswa memanfaatk perpustakaan fakultas. Selain faktor dos faktor penting yang mendorong mahasis memanfaatkan fasilitas perpustakaan ada dari dalam diri mahasiswa sendiri dan $\mathrm{jl}$ teman.

Dari 7 informan dari Fakultas Teknik UG: $57,14 \%$ diantara mereka memanfaatk perpustakaan karena faktor dari dalam c sendiri. Mereka adalah mahasiswa semester 7, 9, dan mahasiswa S2 sehing sudah mempunyai kemandirian dali memanfaatkan perpustakaan. Para inform yang memanfaatkan perpustakaan kare didorong oleh temannya ternyata ada: mahasiswa semester 3. Dengan demikj menurut penulis hal tersebut karena mere masih termasuk mahasiswa awal sehing belum muncul sifat kemandirian dali memanfaatkan perpustakaan.

Dari hasil penelitian dapat diketal bahwa para informan dari Fisipol UGM ya mendapat pengaruh dari teman yaitu 66,67 salah satunya adalah laki-laki semester $3 \dot{c}$ yang lainnya adalah wanita. Dengan demiki dapat diketahui bahwa para mahasiswi cenderu lebih senang memanfaatkan perpustakaan deng temannya. Untuk mahasiswa yang sud semester akhir atau sudah S2 sudah manc dalam memanfaatkan fasilitas perpustaka sehingga mereka memanfaatkan perpustaka karena dorongan dari diri sendiri dan a1 dosennya. Di Perpustakaan Fisipol UG maupun di Fakultas Teknik UGM, mahasis memanfaatkan perpustakaan sebagian be: karena mendapat dorongan dari dosen. Unt mahasiswa tingkat akhir mereka biasanya sud mandiri sehingga dorongan memanfaatk perpustakaan bersumber dari diri sendiri $d$ untuk mahasiswa yang masih tingkat awal at berjenis kelamin wanita biasanya menda] 
dorongan dari temannya. Selain itu dari data yang penulis dapatkan dari informan ternyata latar belakang pendidikan dan ekonomi orang tua mahasiswa tidak begitu mempengaruhi mahasiswa dalam memanfaatkan perpustakaan. Hal ini mungkin karena anaknya sebagai mahasiswa sudah dianggap dewasa dalam memenuhi kebutuhan literatur.

\section{PENUTUP}

\section{A. Kesimpulan}

Dari pembahasan penelitian ini dapat disimpulkan bahwa:

1. Penyelenggaraan perpustakaan fakultas telah mampu memenuhi harapan sivitas akademik. Hal ini mempengaruhi motivasi mahasiswa dalam pemanfaatan perpustakaan yang didorong oleh dirinya sendiri, dosen, teman, dan orang tua.

2. Tujuan pemanfaatan perpustakaan fakultas antara lain untuk memenuhi kebutuhan perkuliahan, meningkatkan prestasi, dan menambah wawasan.

3. Koleksi Perpustakaan Fakultas Teknik UGM dianggap telah memenuhi kebutuhan, jumlahnya memenuhi, meskipun terbitan lama. Kemudian Koleksi Perpustakaan FISIPOL dianggap berkualitas jumlahnya terbatas, dan terbitan lama.

4. Sarana prasarana, tata tertib waktu layanan, kondisi, dan fasilitas perpustakaan Fakultas Teknik dianggap telah memadai. Sementara itu sarana prasarana, situasi dan kondisi, dan fasilitas Perpustakaan FISIPOL UGM perlu ditingkatkan. Namun demikian tata tertib dianggap sudah baik.

\section{B. Rekomendasi}

Untuk meningkatkan motivasi mahasiswa memanfaatkan perpustakaan fakultas maka:

1. Perpustakaan Fakultas Teknik UGM, perlu ada integrasi sistem informasi dengan seluruh perpustakaan jurusan, sarana prasara dan fasilitas yang memadai, dan penataaan ulang ruang perpustakaan agar lebih efektif dan efisien di Fakultas Teknik UGM.

2. Perpustakaan Fisipol UGM, petugas perlu lebih baik lagi dalam melayani pengguna dan menepati waktu layanan, menambah jumlah koleksi baru, dan perbaikan sistem keamanan terhadap barang-barang milik pengguna.

3. Mahasiswa, selalu mencari sumber-sumber informasi lain terutama fasilitas perpustakaan yang telah disediakan fakultas dan mempunyai kesadaran sendiri bahwa memanfaatkan perpustakaan itu suatu kebutuhan untuk meningkatkan pengetahuan dan prestasinya.

\section{Daftar Pustaka}

Arikunto, Suharsimi. Manajemen Penelitian. Jakarta: Rineka Cipta, 2005.

Badan Pengembangan dan Pemberdayaan SDM Kesehatan BPPSDMK.Peran Perpustakaan dalam Mendukung Mutu Pendidikan di Poltekkes Palangkaraya. http://www.bppsdmk.depkes.go.id, diakses 21 Juli 2008.

Black, James A. dan Dean J. Champion. Penerjemah, E. Koeswara. Metode dan Masalah Penelitian Sosial. Bandung: Eresco, 1992.

Dani, Ika Aria. Evaluasi Pelayanan Berdasarkan Standar yang Berlaku dan Persepsi Pasien Baru di Tempat Pendaftaran Pasien (TPP) Rawat Jalan Rumah Sakit PKU Muhammadiyah Yogyakarta (Karya Tulis Ilmiah). Yogyakarta: Fakultas MIPA UGM, 2004.

Hermawan S, Rachman dan Zen, Zulfikar. Etika Kepustakawanan: Suatu Pendekatan Terhadap Profesi dan Kode Etik Pustakawan Indonesia. Jakarta: Sagung Seto, 2006.

Indonesia. Peraturan Pemerintah Republik Indonesia Nomor 153 Tahun 2000 Tentang Penetapan Universitas Gadjah Mada sebagai Badan Hukum Milik Negara. http:/ugm.ac.id Diakses 20 Oktober 2008.

Islamy, M.Irfan. Materi Pokok Kebijakan Publik; 1 9; ADNE4410/3SKS.Jakarta Universitas Terbuka, Depdikbud, 1994. 
Khikmah, Siti Munifatul. Tesis: Hubungan antara Motivasi Belajar dan Konsep Diri Akademik dengan Memori Jangka panjang pada Penghafal Al-Qur'an. Yogyakarta: Sekolah Pasca Sarjana UGM, 2008.

Moleong, Lexy JMetodologi Penelitian Kualitatif . Edisi Revisi, Cet. Ke-25. Bandung: Rosdakarya, 2008.

Nasution, S. Metode Penelitian Naturalistik Kualitatif. Ed. Ke-1, Cet. Ke-3. Bandung: Tarsito, 2003.

Pemerintah Provinsi Jawa Timar. Badan Penelitian dan Pengembangan. Kebijakan Publik. http://www.balitbangjatim.com Diakses Senin, 7 Juli 2008.

Perwirani, Resia. Persepsi Pasien Terhadap Pelayanan pada Tempat Penerimaan Pasien Rawat Jalan di Rumah Sakit Orthopedi Prof $D R \quad R$ Soeharso Surakarta. Yogyakarta: Fakultas MIPA UGM, 2008.

Pujiwati, Sri. Upaya Peningkatan Kualitas Pelayanan Rekam Medis Rumah Sakit Panti Rahayu Purwodadi Grobogan (Karya Tulis Ilmiah). Yogyakarta: Fakultas MIPA UGM, 2003.

Purwantini, Comelio dkk. Laporan Penelitian: Persepsi Siswa, Guru, dan Orang Tua Terhadap Ujian Nasional, Studi Empirik pada SMP-SMP di Kotamadya Yogyakarta. Yogyakarta: Universitas Sanata Dharma, 2006.

Rohmiyati, Yuli. Tesis: Pemanfaatan Perpustakaan Daerah Oleh Masyarakat di Badan Perpustakaan Daerah Yogyakarta. Yogyakarta: Sekolah Pasca Sarjana. 2006.

Sastrodiningrat, Soebagio. Kapita Selekta Manajemen \& Kepemimpinan, Jakarta: Ind-Hill, 1998.

Siagian, Sondang P. Teori Motivasi dan Aplikasinya . Jakarta: Rineka Cipta, 1995.

Sudarsono, Blasius. Antologi Kepustakawanan Indonesia. Jakarta: Pengurus Pusat Ikatan Pustakawan Indonesia bekerja sama dengan Sagung Seto, 2006.

Sudrajat, Akhmad. Teori-teori motivasi. http://akhmadsudrajat.wordpress.com/

Diakses Jum'at, 2 Mei 2008.

Basuki, Sulistyo. Pengantar Ilmu Perpustakaan. Jakarta: Gramedia Pustaka Utama,1993.
Sumarsono, Sonny H.M.Metode Riset Sumber Day Manusia. Yogyakarta: Graha Ilmu, 2004

Sutarno NS. Perpustakan dan Masyarak Jakarta: Yayasan Obor Indonesia, 2003.

Sutarno NS. Tanggung Jawab Perpustakaan dala Mengembangkan Masyarakat Informa Jakarta: Panta Rei, 2005.

Universitas Gadjah Mada. Fakultas Teknik. Lapor Dekan Tahun 2006, Disampaikan pada Di Natalis ke-61 Pendidikan Tinggi Teknik. Februari 2007. Yogyakarta: Fakultas Tekni UGM, 2007.

Fakultas Teknik. Lapor. Dekan Tahun 2007, Disampaikan pada Di Natalis ke-62 Pendidikan Tinggi Teknik. Februari 2008. Yogyakarta: Fakultas Tekni UGM, 2008.

Keputusan Majelis W Amanat No. 12/SK/MWA/2002 Anggart Rumah Tangga UGM. http://ugm.ac Diakses 20 Oktober 2008.

Bersama Merpustakaan UG Perpustakaan-perpustakaan Universit Gadjah Mada. Yogyakarta: Perpustaka: UGM, 2007.

UPT Perpustakac

Lokasi \& Fungsi. http://lib.ugm.ac.id Diaks 20 Oktober 2008.

Utama, Surya. Dasar-dasar Analisis Kebijak Kesehatan. http://www.library.usu.ac. Diakses Senin, 7 Juli 2008.

Walgito, Bimo. Pengantar Psikologi Umu Yogyakarta: Andi, 1997.
-----.-----.. Pengantar Psikologi Umu. Yogyakarta: Andi, 2004. Psikologi Sosial: Suatu Pengantar. Yogyakarta: Andi, 1991. 